CLINICAL STUDY

\title{
Expression of thyroid hormone transporters during critical illness
}

\author{
Liese Mebis $^{1}$, Deborah Paletta ${ }^{1}$, Yves Debaveye ${ }^{1}$, Björn Ellger ${ }^{1}$, Lies Langouche ${ }^{1}$, André D’Hoore ${ }^{2}$, Veerle M Darras ${ }^{3}$, \\ Theo J Visser ${ }^{4}$ and Greet Van den Berghe ${ }^{1}$ \\ ${ }^{1}$ Department of Intensive Care Medicine, ${ }^{2}$ Department of Abdominal Surgery and ${ }^{3}$ Laboratory of Comparative Endocrinology, Katholieke Universiteit \\ Leuven, B-3000 Leuven, Belgium and ${ }^{4}$ Department of Internal Medicine, Erasmus University Medical Center, 3015 GE Rotterdam, The Netherlands
}

(Correspondence should be addressed to G Van den Berghe; Email: greet.vandenberghe@med.kuleuven.be)

\begin{abstract}
Objective: Prolonged critically ill patients have low circulating thyroid hormone (TH) levels without a rise in TSH, a condition labeled 'the low tri-iodothyronine $\left(\mathrm{T}_{3}\right)$ syndrome'. Currently, it is not clear whether this represents an adaptive response. We examined the role of $\mathrm{TH}$ transporters monocarboxylate transporter 8 (MCT8, also known as SLC16A2) and MCT10 in the pathogenesis of the low $\mathrm{T}_{3}$ syndrome in prolonged critical illness.

Methods: A clinical observational study in critically ill patients and an intervention study in an in vivo animal model of critical illness. Gene expression levels of MCT8 and MCT1O were measured by realtime PCR.

Results: In prolonged critically ill patients, we measured increased MCT8 but not MCT1O gene expression levels in liver and skeletal muscle as compared with patients undergoing acute surgical stress. In a rabbit model of prolonged critical illness, gene expression levels of MCT8 in liver and of MCT1O in skeletal muscle were increased as compared with healthy controls. Treatment of prolonged critically ill rabbits with $\mathrm{TH}$ (thyroxine $+\mathrm{T}_{3}$ ) resulted in a downregulation of gene expression levels of MCT8 in liver and of MCT1O in muscle. Transporter expression levels correlated inversely with circulating TH parameters.

Conclusions: These data suggest that alterations in the expression of TH transporters do not play a major role in the pathogenesis of the 'low $\mathrm{T}_{3}$ syndrome' but rather reflect a compensatory effort in response to hypothyroidism.
\end{abstract}

European Journal of Endocrinology $161243-250$

\section{Introduction}

Critically ill patients have low circulating triiodothyronine $\left(\mathrm{T}_{3}\right)$ levels while $\mathrm{rT}_{3}$ levels are increased $(1,2)$. TSH levels, measured in a single sample, are normal to low (3). These changes are the result of complex alterations that occur in the hypothalamicpituitary-thyroid (HPT) axis and are commonly referred to as the 'low $\mathrm{T}_{3}$ syndrome' or 'non-thyroidal illness' or 'euthyroid sick syndrome'. Importantly, there are distinct differences between the acute phase and the chronic phase of critical illness (4). In the acute phase, the alterations predominantly occur in peripheral tissues, resulting in inactivation of thyroid hormone (TH). Subtle changes in the central part of the HPT axis, however, can already be observed in the acute phase of critical illness with a rise in hypothalamic D2 $(5,6)$ and a transient rise in serum levels of thyrotropin (7). These disturbances are uniformly present in different types of acute illnesses and could be interpreted as an attempt of the body to reduce energy expenditure. In the prolonged phase of critical illness, there is an additional neuroendocrine component characterized by suppressed hypothalamic TRH expression levels $(8,9)$. It is unclear whether in this unnatural state, low circulating TH levels remain beneficial. However, there is no clear clinical evidence advocating $\mathrm{TH}$ treatment in such patients.

The peripheral conversion of $\mathrm{TH}$ is regulated by the intracellular enzymes iodothyronine deiodinases (10). It has recently been shown that disturbances of the peripheral metabolism of TH may play an important role in the pathogenesis of the 'low $\mathrm{T}_{3}$ syndrome' $(11,12)$. However, before TH can be converted, it needs to be transported over the plasma membrane in order to be available for subsequent metabolism (13). Monocarboxylate transporter 8 (MCT8, also known as SLC16A2) has recently been shown to be a very active and specific $\mathrm{TH}$ transporter $(14,15)$. It was originally named X-linked PEST-containing transporter (16) and has affinity for thyroxine $\left(\mathrm{T}_{4}\right), \mathrm{T}_{3}$, and $\mathrm{rT}_{3}(14)$. Human MCT8 is shown to be expressed in various tissues such as heart, brain, liver, skeletal muscle, and kidney (16). Recently, analysis of two MCT8 knockout models 
$(17,18)$ showed marked alterations in circulating $\mathrm{TH}$ concentrations, with increased $\mathrm{T}_{3}$ and TSH and decreased $\mathrm{T}_{4}$ levels, as seen in affected humans $(19,20)$. In these knockout mice, cell-specific changes in intracellular $\mathrm{TH}$ content coincided with differences in intracellular deiodinase activity levels $(17,18)$. Previous studies suggested the involvement of a T-type amino acid transporter in the uptake of iodothyronines in different cell types (21-23). MCT10 was identified as a T-type amino-acid transporter $(24,25)$ and was recently shown to be very active for TH transport (26). It is also a member of the MCT family and shows a particular high homology with MCT8. Human MCT10 (TAT1, SLC16A10) is expressed in heart, skeletal muscle, kidney, placenta, and intestine (25).

The precise role of TH transporters in the pathogenesis of the low $\mathrm{T}_{3}$ syndrome in prolonged critical illness remains to be unknown. We analyzed MCT8 and MCT10 expression levels in human skeletal muscle and liver biopsies from prolonged critically ill patients in comparison with those from patients undergoing acute surgical stress. In addition, we used an in vivo animal model of prolonged critical illness to examine the gene expression levels of MCT8 and MCT1O in liver, muscle, and kidney. We also studied the effect of intravenous $\mathrm{T}_{4}$ and $\mathrm{T}_{3}$ infusion, resulting in an increase of the circulating $\mathrm{TH}$ levels, on transporter expression levels in order to assess the ability of the thyroid status to regulate $\mathrm{TH}$ transporters in this condition of critical illness.

\section{Materials and methods}

\section{Human model}

We studied prolonged critically ill patients who participated in a large randomized controlled study on the effects of intensive insulin treatment in intensive care unit (ICU) patients $(n=1548)$, of whom the major clinical outcomes have been published in detail previously (27). From 98 patients who had died in the ICU, postmortem biopsy samples of skeletal muscle (right musculus rectus abdominis) and liver were taken within minutes after death. Of these, 21 patients had been treated with $\mathrm{TH}$ at some time during the course of critical illness and were excluded from this study. Ultimately, good quality RNA from postmortem liver and skeletal muscle biopsies was available from 44 patients. Tissue samples were snap-frozen in liquid nitrogen and stored at $-80{ }^{\circ} \mathrm{C}$ until further analysis. Daily blood samples were collected and stored at $-80{ }^{\circ} \mathrm{C}$. Analysis was done on blood samples from the last morning before death.

For comparison, we studied skeletal muscle (right musculus rectus abdominis) and liver biopsy samples harvested from 22 age, gender, and body mass index matched patients (Table 1) during elective abdominal surgery.
Table 1 Demographic characteristics of the studied prolonged critically ill patients and patients undergoing acute surgical stress.

\begin{tabular}{|c|c|c|c|}
\hline & $\begin{array}{l}\text { Acute surgical } \\
\text { stress } \\
n=22\end{array}$ & $\begin{array}{l}\text { Prolonged } \\
\text { critically ill } \\
n=44\end{array}$ & $P$ \\
\hline Gender ( $n$, male) & $14(64 \%)$ & $31(70 \%)$ & 0.6 \\
\hline $\begin{array}{l}\text { Age (years; } \\
\text { mean } \pm \text { S.D.) }\end{array}$ & $69 \pm 12$ & $69 \pm 14$ & 0.8 \\
\hline BMI (mean \pm s.D.) & $25.1 \pm 2.6$ & $25.7 \pm 3.7$ & 0.5 \\
\hline $\begin{array}{l}\text { Days in ICU } \\
\text { before death } \\
\text { (median - IQR) }\end{array}$ & - & $11(6-28)$ & - \\
\hline
\end{tabular}

$P$ values for age and BMI represent Student $t$-tests. $P$ value for gender represents $\chi^{2}$ test.

All protocols were approved by the Institutional Review Board of the Leuven University. Written informed consent was obtained from all healthy volunteers and from the patients or the closest family member, when the patient was unable to give consent.

\section{In vivo animal experiment}

All animals were treated according to the Principles of Laboratory Animal Care formulated by the US National Society for Medical Research and the Guide for the Care and Use of Laboratory Animals prepared by the National Institutes of Health. The study protocol was approved by the Leuven University ethical review board for animal research (P03052).

The model has been described in detail previously (11, 28). In brief, male New Zealand white rabbits were anesthetized and a full thickness burn injury equaling $15-20 \%$ of the total body surface area was imposed. Blood glucose levels were kept below $180 \mathrm{mg} / \mathrm{dl}$ by frequent blood glucose monitoring and titration of insulin infusion (100 IU/ml; Actrapid Novolet, Novo Nordisk, Bagsvaerd, Denmark; via an SE200B infusion pump, Vial Medical, Brezins, France) when necessary. This model has been validated as representative of the human critically ill condition (11, 28). After 4 days, surviving rabbits were randomized by sealed envelopes to receive a 4 day continuous infusion of $0.9 \% \mathrm{NaCl}$ (saline group, $n=7$ ) or $5 \mu \mathrm{g} / \mathrm{kg}$ per day $\mathrm{T}_{3}$ plus $9 \mu \mathrm{g} / \mathrm{kg}$ per day $\mathrm{T}_{4}\left(\mathrm{~T}_{3}+\mathrm{T}_{4}\right.$ group, $\left.n=8\right)$ (Fig. 1). We first used $\mathrm{T}_{4}$ and $\mathrm{T}_{3}$ substitution doses but these did not result in significantly elevated serum $\mathrm{TH}$ levels, therefore we increased the doses to ensure elevated levels of $\mathrm{TT}_{4}$ and $\mathrm{TT}_{3}$ in the circulation. On day 8 , animals were killed and samples were taken from upper limb skeletal muscle, liver and kidney and snap-frozen in liquid nitrogen, after which they were stored at $-80^{\circ} \mathrm{C}$ until further analysis. For comparison, four healthy rabbits were killed at the day of arrival and tissue samples were collected as described above. 


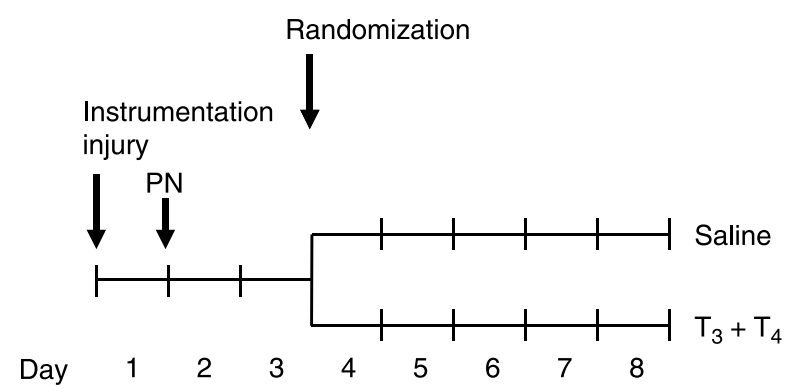

Figure 1 Flow chart of rabbit study design. Animals were randomized on day 4 after prelevation of a reference sample. Interventions were continued for 4 days. PN, parenteral nutrition.

\section{Determination of $\mathrm{T}_{4}, \mathrm{~T}_{3}$, and $\mathrm{rT}_{3}$ concentrations in serum}

Human samples Commercial RIAs were used to determine total serum $\mathrm{T}_{4}, \mathrm{~T}_{3}$, TSH (Immunotech SAS, Marseille, France), and $\mathrm{rT}_{3}$ (Biocode Hycel, Liège, Belgium) concentrations. The detection limits were $13 \mathrm{nmol} / \mathrm{l}, 0.1 \mathrm{nmol} / \mathrm{l}, 0.025 \mathrm{mIU} / \mathrm{l}$, and $0.008 \mathrm{nmol} / \mathrm{l}$ for $\mathrm{T}_{4}, \mathrm{~T}_{3}, \mathrm{TSH}$, and $\mathrm{rT}_{3}$ respectively. The intra-assay coefficient of variation $(\mathrm{CV})$ for each was 5.1, 3.3, 3.7 and $3 \%$ respectively. All samples were assayed in duplicate. Results were compared with previously reported reference values from 25 matched healthy controls (29).

Rabbit samples Plasma concentrations of TSH were measured by a specific RIA (reagents provided by Dr A Parlow, National Pituitary Agency). The detection limit was $1.2 \mathrm{mIU}$, and the intra-assay CV was $5.3 \%$. For samples below detection limit, a value representing half the detection limit was entered. Total concentrations of plasma $\mathrm{T}_{4}, \mathrm{~T}_{3}$, and $\mathrm{rT}_{3}$ were determined by an in-house RIA (30). The detection limits were 0.005, 0.002, and
$0.005 \mathrm{pmol} / \mathrm{l}$ respectively. The intra-assay $\mathrm{CV}$ were 9.2 , 6.4 , and $9.7 \%$ respectively. No free hormone determinations were done because blood sampling was performed with heparinized catheters which substantially interferes with the assay used to quantify free concentrations of TH (31).

\section{Determination of $T_{4}, T_{3}$, and $r T_{3}$ concen- trations in human skeletal muscle}

$\mathrm{T}_{4}, \mathrm{~T}_{3}$, and $\mathrm{rT}_{3}$ were determined by highly sensitive and specific RIAs after extraction and purification of the iodothyronines from skeletal muscle, as described previously $(32-34) .\left[{ }^{131} \mathrm{I}\right] \mathrm{T}_{4}$ and $\left[{ }^{125} \mathrm{I}\right] \mathrm{T}_{3}$ of two thousand counts per minute were added to each sample as internal tracers for recovery calculations. Average recovery was $55.4 \%$ for $\left[{ }^{131} \mathrm{I}^{\mathrm{I}} \mathrm{T}_{4}\right.$ and $72.3 \%$ for $\left[{ }^{125} \mathrm{I}\right] \mathrm{T}_{3}$. Owing to the limited amount of available tissue, $\left[{ }^{125} \mathrm{I}\right] \mathrm{T}_{4}$ was also used as a recovery tracer for the determination of $\mathrm{rT}_{3}$. No corrections for the amounts of iodothyronines contributed by the blood trapped in the tissue aliquot were performed.

\section{Cloning of rabbit genes}

Total RNA was isolated from rabbit liver tissue using Qiazol lysis reagent (Qiagen) and subsequently purified using the RNeasy mini RNA isolation kit (Qiagen). cDNA was obtained by reverse transcription of $2 \mu \mathrm{g}$ total RNA using random hexamer primers. Oligonucleotides homologous to sequences surrounding the start or stop codons of human, mouse, and rat Mct8 and Mct10 were designed and used for PCR. The amplified fragments were cloned into the pGEM-T vector followed by sequence analysis. These sequences showed high amino acid identity with the corresponding genes from other mammalian species and data have been submitted to the GenBank database under accession numbers

Table 2 Real-time PCR primers and probes.

\begin{tabular}{|c|c|}
\hline Gene name (Genbank accession number) & Sequence \\
\hline осMCT8 (EF420874) & $\begin{array}{l}\text { Forward: } 5^{\prime} \text {-CCATGTGGCCTTCTACTTTGC-3' } \\
\text { Probe: 5'-CCCCCCATCATTGGAGCTGTCATC-3' } \\
\text { Reverse: } 5^{\prime} \text {-TGCATCAGAGGGACGAAGAAA-3' }\end{array}$ \\
\hline ocMCT10 (EF489851) & $\begin{array}{l}\text { Forward: } 5^{\prime} \text {-TCCGAGCAGAAATCCAATCG-3' } \\
\text { Probe: } 5^{\prime}-3^{\prime} \\
\text { Reverse: } 5^{\prime} \text {-GGCTCCCACACATCCCGGGCACC-3' }\end{array}$ \\
\hline ocHPRT (AF020294) & $\begin{array}{l}\text { Forward: } 5^{\prime} \text {-TGTAGATTTTATCAGACTGAAGAGCTACTGT-3' } \\
\text { Probe: } 5^{\prime} \text {-TTTCCAGTTAAGGTTGAGAGATCATCTCCACCGAT-3' } \\
\text { Reverse: } 5^{\prime} \text {-AAGGAAAGCAAGGTCTGCATTGTT-3' }\end{array}$ \\
\hline hsMCT8 (NM_006517) & $\begin{array}{l}\text { Forward: } 5^{\prime} \text {-CCCTGTGCCGGGACTTC-3' } \\
\text { Probe: } 5^{\prime} \text {-CCTTTGCGATGGCTTCTTCATCACCA-3' } \\
\text { Reverse: } 5^{\prime} \text {-CACCAGCTCAAATGCAATGG-3' }\end{array}$ \\
\hline hsMCT10 (NM_018593) & $\begin{array}{l}\text { Forward: } 5^{\prime}-\text { GGCTCCTATGATGTGGCATTCT-3' } \\
\text { Probe: 5'-CCTCGCTGGAGTCCCTCCCCTTATTG-3' } \\
\text { Reverse: } 5^{\prime} \text {-TCCACGGGATAAAACAAAGCA-3' }\end{array}$ \\
\hline hsHPRT (NM_000194.1) & $\begin{array}{l}\text { Forward: } 5^{\prime} \text {-TGTAGGATATGCCCTTGACTATAATGAA-3' } \\
\text { Probe: } 5^{\prime} \text {-TGGAAAAGCAAAATACAAAGCCTAAGATGAGAGTT-3' } \\
\text { Reverse: } 5^{\prime} \text {-AATAGGACTCCAGATGTTTCCAAA-3 }{ }^{\prime}\end{array}$ \\
\hline
\end{tabular}


EF420874 (MCT8) and EF489851 (MCT1O). Based on these sequences, we designed specific primers and probes for real-time PCR analysis using Primer Express software v 2.0 (Applied Biosystems, Foster City, CA, USA).

\section{RNA isolation and real-time PCR}

Total RNA from skeletal muscle, liver, and kidney was isolated using Qiazol lysis reagent (Qiagen) and subsequently purified using the RNeasy mini RNA isolation kit (Qiagen) and quantified by Nanodrop spectrophotometer (ND-1000, Nanodrop Technologies, Wilmington, DE, USA). Samples were treated with DNase to remove all contaminating genomic DNA. In total $1 \mu \mathrm{g}$ RNA was reverse-transcribed with Superscript III Reverse Transcriptase (Invitrogen) using random primers (Invitrogen). All samples were reverse transcribed simultaneously. Reactions lacking reverse transcriptase were also run as a control for genomic DNA contamination.

Human and rabbit MCT8 and MCT1O mRNA levels were quantified in real time with the ABI PRISM 7700 sequence detector (Applied Biosystems) which uses TaqMan chemistry for highly accurate quantification of mRNA levels. Sequences of the primers and probes are given in Table 2 . The $10 \mu \mathrm{l}$ real time reaction mixture contained $5 \mu \mathrm{l}$ TaqMan Fast Universal PCR Master Mix (Applied Biosystems), $0.5 \mu \mathrm{l}$ forward primer, $0.5 \mu \mathrm{l}$ reverse primer, $0.5 \mu \mathrm{l}$ TaqMan probe ([5']6-FAM [3']BHQ-1 labeled), $0.5 \mu \mathrm{l}$ water, and $3 \mu \mathrm{l} \mathrm{cDNA}$ (7.5 ng). Unknown samples were run in duplicate and individual samples with a $C_{\mathrm{t}}$ value standard deviation $>0.3$ were reanalyzed. Data were analyzed using the comparative $C_{\mathrm{t}}$ method. Gene expression of hypoxanthine guanine phosphoribosyl transferase (HPRT) remained stable in all experimental groups of our human and rabbit study population and was therefore used as an internal control.

\section{Statistical analysis}

All statistical analyses were done using StatView software (SAS Institute Inc., Cary, NC, USA). Data were analyzed using one-way ANOVA tests with a post hoc Fisher's least significant difference test for multiple comparisons and $\chi^{2}$ tests, when appropriate. Data are presented as means \pm s.D. or medians and interquartile ranges when appropriate. Statistical significance was assumed for a two-sided $P$ value $<0.05$.

\section{Results}

\section{Human model}

Prolonged critically ill patients $(n=44)$ showed lower circulating total $\mathrm{T}_{3}\left(\mathrm{TT}_{3}\right), \mathrm{TT}_{4}$, and $\mathrm{TSH}$ levels and higher $\mathrm{rT}_{3}$ levels as compared with patients undergoing acute surgical stress $(n=22$; Fig. 2A)
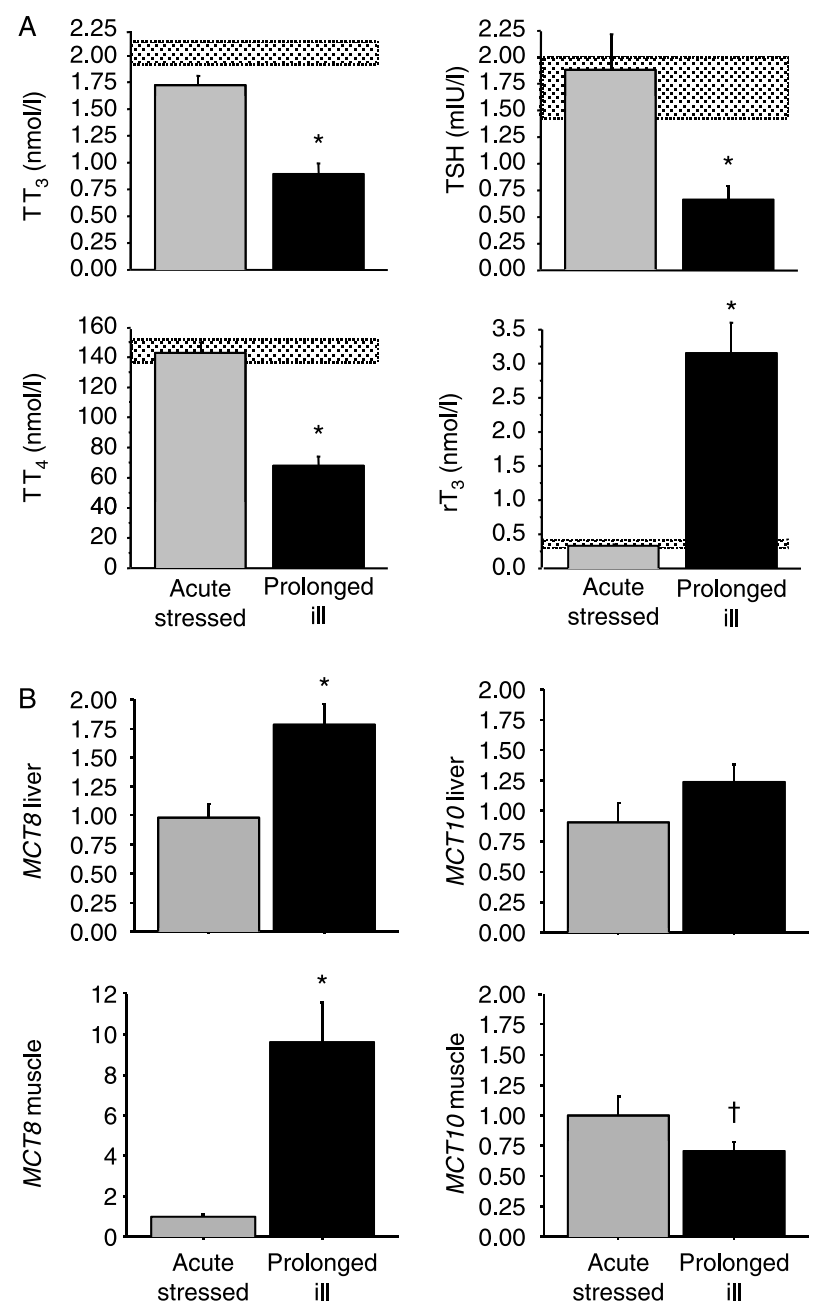

Figure 2 (A) Circulating thyroid hormone parameters in acutely stressed (gray bars, $n=22$ ) and chronically ill patients (black bars, $n=64)$. The shaded area designates the normal range. (B) Relative MCT8 and MCT10 mRNA expression levels measured in liver and skeletal muscle of acutely stressed and chronically ill patients. Data are expressed as mean \pm S.E.M. ${ }^{*} P<0.05$ versus acute values; ${ }^{\dagger} P=0.05$ versus acute values.

which is characteristic for the low $\mathrm{T}_{3}$ syndrome. Eighteen prolonged critically ill patients $(41 \%)$ had been treated with dopamine at some time during their ICU stay, but this did not result in significantly different circulating $\mathrm{TT}_{3}(P=0.5), \mathrm{TT}_{4}(P=0.8)$, TSH $(P=0.2)$ or $\mathrm{rT}_{3}(P=0.5)$ levels on the moment of the assay as compared with the patients who had not received dopamine.

We analyzed gene expression of TH transporter MCT8 and observed a marked increase in both liver and skeletal muscle of prolonged ill patients as compared with patients undergoing acute surgical stress (Fig. 2B). Expression of the TH transporter MCT1O in liver and skeletal muscle was not significantly different between acute and chronically ill patients (Fig. 2B). 
MCT8 and MCT10 protein expression analysis in liver and skeletal muscle samples was tested but did not yield satisfactory results.

Since we observed the most dramatic change in gene expression for MCT8 in skeletal muscle, we examined in this tissue whether the change in MCT8 gene expression was associated with changes in circulating $\mathrm{TH}$ concentrations and/or with tissue $\mathrm{TH}$ concentrations. In the entire study population (acute surgical stress controls and prolonged critically ill patients), we found a significant inverse correlation between skeletal muscle MCT8 mRNA and serum $\mathrm{TT}_{3}$ $(P<0.001, \quad R=-0.6), \mathrm{TT}_{4}(P<0.001, \quad R=-0.5)$, and $\mathrm{T}_{3} / \mathrm{rT}_{3}(P<0.001, R=-0.6)$. Serum iodothyronine levels are positively correlated with tissue levels, as described previously (34). Within the prolonged critically ill patients, selectively, we found a significant positive correlation between skeletal muscle MCT8 mRNA and tissue $\mathrm{T}_{3}(P=0.05, R=0.4)$ and $\mathrm{T}_{4}$ $(P=0.02, R=0.4)$.

\section{In vivo animal experiment}

Our animal model of prolonged critical illness is characterized by low circulating $\mathrm{T}_{3}(P<0.001$ versus healthy controls) concentrations and low-normal $\mathrm{T}_{4}$ levels (Fig. 3A), as previously described (11).

We first analyzed MCT8 and MCT1O gene expression in liver, skeletal muscle, and kidney. In liver of prolonged critically ill rabbits, we found an increase in MCT8 but not MCT1O gene expression levels as compared with healthy control animals (Fig. 3B). In skeletal muscle of prolonged critically ill rabbits, MCT1O but not MCT8 mRNA was strongly increased as compared with healthy controls (Fig. 3B). In kidney, there was no significant change in MCT8 or MCT1O gene expression levels between prolonged ill and control rabbits.

We used our rabbit model of prolonged critical illness to examine, in a controlled setting, whether MCT8 or MCT1O gene expression can be affected by alterations in circulating TH levels during prolonged critical illness. Treatment of prolonged critically ill rabbits with a 4-day infusion of $\mathrm{T}_{3}$ and $\mathrm{T}_{4}$ significantly increased circulating $\mathrm{T}_{3}$ and $\mathrm{T}_{4}$ levels (Fig. 3A). The exogenous administration of $\mathrm{T}_{3}$ and $\mathrm{T}_{4}$ reduced MCT8 mRNA in liver and MCT1O mRNA levels in skeletal muscle as compared with saline-treated ill rabbits (Fig. 3B). In the liver, we found a significant negative correlation between MCT8 mRNA levels and plasma $\mathrm{T}_{3}(P=0.03, R=-0.5)$. MCT1O mRNA in skeletal muscle showed a significant negative correlation with plasma $\mathrm{T}_{3}(P<0.001$, $R=-0.7), \quad \mathrm{T}_{4} \quad(P=0.002, \quad R=-0.6), \quad$ and $\mathrm{TSH}$ $(P=0.008, R=-0.6)$. In kidney, no effect of $\mathrm{TH}$ treatment was observed on gene expression levels of the studied transporters.
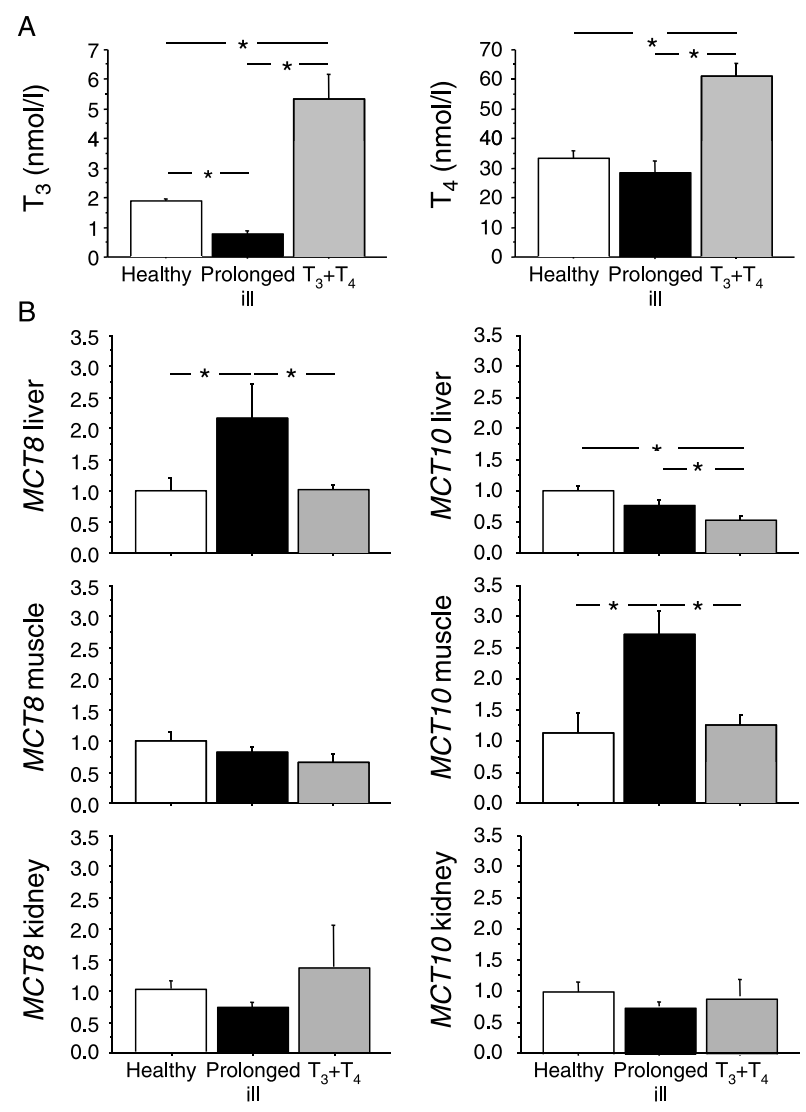

Figure $3(A)$ Circulating thyroid hormone concentrations in healthy control rabbits, saline treated prolonged ill rabbits, and $T_{3}+T_{4}$ treated ill rabbits. (B) Relative expression levels of MCT8 and MCT1O in liver and muscle of healthy control rabbits, saline treated prolonged ill rabbits, and $T_{3}+T_{4}$ treated ill rabbits. Data are expressed as mean \pm s.E.M. ${ }^{*} P<0.05$.

\section{Discussion}

We set out to study the role of TH transporters in the pathogenesis of the low $\mathrm{T}_{3}$ syndrome, and its regulation by thyroid status during prolonged critical illness.

In the human study, prolonged critically ill patients showed increased MCT8 gene expression in liver as well as skeletal muscle. MCT1O gene expression was not altered in human liver or in human skeletal muscle. Interestingly, we found a significant inverse correlation between circulating TH parameters and MCT8 gene expression in skeletal muscle. This means that patients with the lowest serum $\mathrm{TT}_{3}$ and $\mathrm{TT}_{4}$ levels show the highest upregulation of MCT8 mRNA. This is also reflected by an inverse correlation between the ratio of active over inactive $\mathrm{TH}, \mathrm{T}_{3} / \mathrm{rT}_{3}$ ratio, and MCT8 gene expression, meaning that the sickest patients, with the lowest $\mathrm{T}_{3} / \mathrm{rT}_{3}$ ratio, have a higher induction of MCT8 gene expression. We were not successful in measuring MCT8 protein expression levels, and hence we do not know whether increased MCT8 gene expression was 
effectively associated with increased transporter activity. However, within the prolonged critically ill patient group, MCT8 mRNA showed a significant positive correlation with skeletal muscle $\mathrm{T}_{3}$ and $\mathrm{T}_{4}$. At the first sight, this may seem contradictive, as in the entire study population (acutely stressed controls and prolonged critically ill patient studied together), there was an inverse correlation. The positive correlation in the patients between MCT8 mRNA and the low tissue $\mathrm{T}_{3}$ levels, could suggest that the upregulated MCT8 may have evoked a small increase in tissue $\mathrm{T}_{3}$ levels, although these remained low when compared to controls. Hence, this seemingly adaptive response, if present, was clearly insufficient to normalize tissue TH levels, possibly in part related to a reduced $\mathrm{TH}$ availability in the circulation.

In the rabbit model of prolonged critical illness, in the presence of low circulating $\mathrm{T}_{3}$, MCT8 expression was increased in liver and MCT1O in skeletal muscle as compared with healthy controls. No changes were observed in kidney. Despite these dissimilarities between the human and animal observations, the net result was similar, being an increase in $\mathrm{TH}$ transporter gene expression levels in skeletal muscle and liver during prolonged critical illness. The difference between human and rabbit TH transporter expression can be due to species differences as has been described for the expression of TH transporters in the brain of mice, rats, and humans (35).

We were interested to test the hypothesis that circulating $\mathrm{TH}$ levels can affect $\mathrm{TH}$ transporter gene expression during critical illness. This cannot be done in a clinical setting as only the sickest patients receive $\mathrm{TH}$ treatment. We used our rabbit model of prolonged critical illness to examine in a controlled setting, independent of other illness associated factors, whether MCT8 or MCT1O gene expression is regulated by circulating $\mathrm{TH}$ levels during prolonged critical illness. Treatment of prolonged critically ill rabbits with a combination of $\mathrm{T}_{3}$ and $\mathrm{T}_{4}$, thereby increasing circulating levels of $\mathrm{T}_{3}$ and $\mathrm{T}_{4}$ to supranormal levels, reduced transporter expression levels in all tissues studied except kidney. Also, circulating $\mathrm{TH}$ parameters correlated inversely with the different transporter gene expression levels. Previous studies by our group showed that tissue iodothyronine levels in prolonged critically ill rabbits correlate well with circulating iodothyronine levels (36). Together, these data suggest that TH transporter expression levels are regulated by the TH status during prolonged critical illness resulting in increased MCT8 or MCT10 expression levels when circulating and tissue iodothyronine levels are low and a decrease in MCT8 and MCT10 expression when circulating and tissue iodothyronine levels are high. We acknowledge that infusion of $\mathrm{T}_{3}+\mathrm{T}_{4}$ resulted in higher plasma $\mathrm{T}_{3}$ and $\mathrm{T}_{4}$ concentrations than healthy control rabbits have. However, this relative overdosing is not disadvantageous in the context of our study. Although liver and skeletal muscle of prolonged ill animals showed increased MCT8 or MCT1O expression levels, there was no upregulation in kidney. This does not exclude that other TH transporting molecules may be upregulated in this tissue (37).

Together, the data suggest that $\mathrm{TH}$ transporters are not involved in the pathogenesis of the 'low $\mathrm{T}_{3}$ syndrome' during prolonged critical illness. Early studies have reported decreased $\mathrm{T}_{4}$ transport into tissues in patients with low $\mathrm{T}_{3}$ syndrome (38-40). These findings could be reconciled with our observations if other TH transporters would be decreased. Alternatively, since patients with low $\mathrm{T}_{3}$ syndrome are often in a negative energy balance, and may suffer from mitochondrial dysfunction (41), hepatic ATP depletion may impair energy dependent $\mathrm{TH}$ transport $(42,43)$. Furthermore, serum of critically ill patients can inhibit the uptake of $\mathrm{T}_{4}$ into cultured hepatocytes (44-46). This observation has led to the identification of several inhibitors, such as indoxyl sulfate, non-esterified fatty acids, and bilirubin which circulate in increased concentrations during critical illness (44-47).

Some limitations of the two experiments should be highlighted. First, biopsies from prolonged ill patients were obtained within minutes after death in contrast to those obtained during anesthesia from patients undergoing acute surgical stress. However, there was no correlation between $\mathrm{TH}$ transporter expression levels and postmortem time delay. Second, our animal model of burn injury-induced critical illness may mirror only part of the complex entity of human critical illness. This may explain the observed discrepancy between MCT1O expression levels in human and rabbit skeletal muscle during prolonged illness.

Our conclusions are that gene expression level of the TH transporter MCT8 and/or MCT1O is upregulated during prolonged critical illness and this upregulation is positively associated with the severity of the low $\mathrm{T}_{3}$ syndrome. When circulating TH levels are increased by exogenous infusion during prolonged critical illness, TH transporter gene expression levels are lowered. These data show that some tissues may try to adapt to the low circulating $\mathrm{T}_{3}$ levels by increasing expression of $\mathrm{TH}$ transporters. This could increase the tissue availability of $\mathrm{TH}$, without resulting in a normalization of the tissue $\mathrm{TH}$ concentrations. This may suggest that the 'low $\mathrm{T}_{3}$ syndrome' in prolonged critical illness may not necessarily represent an adaptive 'euthyroid state' for all organ systems.

\section{Declaration of interest}

We declare that there is no conflict of interest that could be perceived as prejudicing the impartiality of the research reported.

\section{Funding}

This work was supported by the Research Fund - Flanders, Belgium (FWO) (G.025805), long-term structural Funding-Methusalem funding by the Flemish Government, PhD-scholarship, Aspirantenmandaat to Y D, the Research Fund of the University of Leuven (GOA/2007/14) 
and a research grant from the Innovative Medizinische Forschung (EL 610304) and from B Braun Stiftung, Germany, to B Ellger. Y D is now affiliated to the Department of Intensive Care Medicine, Europe Hospitals, Brussels, Belgium. B E is now affiliated to the Department for Anesthesiology and Intensive Care Medicine, University Hospital Münster, Germany. L Langouche is a Postdoctoral Fellow for the FWO.

\section{Acknowledgements}

We wish to thank P Wouters, I Milants, W Coopmans, E Van Herck, W Van Ham, I Proven, and L Noterdaeme for their excellent technical assistance.

\section{References}

1 Docter R, Krenning EP, de Jong M \& Hennemann G. The sick euthyroid syndrome: changes in thyroid hormone serum parameters and hormone metabolism. Clinical Endocrinology 199339 499-518.

2 Wartofsky L \& Burman KD. Alterations in thyroid function in patients with systemic illness: the "euthyroid sick syndrome". Endocrine Reviews 19823 164-217.

3 Van den Berghe G. Dynamic neuroendocrine responses to critical illness. Frontiers in Neuroendocrinology 200223 370-391.

4 Van den Berghe G, de Zegher F \& Bouillon R. Acute and prolonged critical illness as different neuroendocrine paradigms. Journal of Clinical Endocrinology and Metabolism 199883 1827-1834.

5 Boelen A, Kwakkel J, Thijssen-Timmer DC, Alkemade A, Fliers E \& Wiersinga WM. Simultaneous changes in central and peripheral components of the hypothalamus-pituitary-thyroid axis in lipopolysaccharide-induced acute illness in mice. Journal of Endocrinology 2004182 315-323.

6 Fekete C, Gereben B, Doleschall M, Harney JW, Dora JM, Bianco AC, Sarkar S, Liposits Z, Rand W, Emerson C, Kacskovics I, Larsen PR \& Lechan RM. Lipopolysaccharide induces type 2 iodothyronine deiodinase in the mediobasal hypothalamus: implications for the nonthyroidal illness syndrome. Endocrinology $20041451649-1655$.

7 Michalaki M, Vagenakis AG, Makri M, Kalfarentzos F \& Kyriazopoulou V. Dissociation of the early decline in serum T(3) concentration and serum IL- 6 rise and TNFalpha in nonthyroidal illness syndrome induced by abdominal surgery. Journal of Clinical Endocrinology and Metabolism 200186 4198-4205.

8 Fliers E, Guldenaar SE, Wiersinga WM \& Swaab DF. Decreased hypothalamic thyrotropin-releasing hormone gene expression in patients with nonthyroidal illness. Journal of Clinical Endocrinology and Metabolism 199782 4032-4036.

9 Van den Berghe G, de Zegher F, Baxter RC, Veldhuis JD, Wouters P, Schetz M, Verwaest C, Van der Vorst E, Lauwers P, Bouillon R \& Bowers CY. Neuroendocrinology of prolonged critical illness: effects of exogenous thyrotropin-releasing hormone and its combination with growth hormone secretagogues. Journal of Clinical Endocrinology and Metabolism $1998 \mathbf{8 3} 309-319$.

10 Bianco AC, Salvatore D, Gereben B, Berry MJ \& Larsen PR. Biochemistry, cellular and molecular biology, and physiological roles of the iodothyronine selenodeiodinases. Endocrine Reviews 200223 38-89.

11 Debaveye Y, Ellger B, Mebis L, Van Herck E, Coopmans W, Darras V \& Van den Berghe G. Tissue deiodinase activity during prolonged critical illness: effects of exogenous thyrotropin-releasing hormone and its combination with growth hormone-releasing peptide-2. Endocrinology 2005146 5604-5611.

12 Peeters RP, Wouters PJ, Kaptein E, van Toor H, Visser TJ \& Van den Berghe G. Reduced activation and increased inactivation of thyroid hormone in tissues of critically ill patients. Journal of Clinical Endocrinology and Metabolism $2003 \mathbf{8 8} 3202-3211$.
13 Hennemann G, Krenning EP, Polhuys M, Mol JA, Bernard BF, Visser TJ \& Docter R. Carrier-mediated transport of thyroid hormone into rat hepatocytes is rate-limiting in total cellular uptake and metabolism. Endocrinology 1986119 1870-1872.

14 Friesema EC, Ganguly S, Abdalla A, Manning Fox JE, Halestrap AP \& Visser TJ. Identification of monocarboxylate transporter 8 as a specific thyroid hormone transporter. Journal of Biological Chemistry $20032 \mathbf{2 7 8} 40128-40135$.

15 Friesema EC, Kuiper GG, Jansen J, Visser TJ \& Kester MH. Thyroid hormone transport by the human monocarboxylate transporter 8 and its rate-limiting role in intracellular metabolism. Molecular Endocrinology 200620 2761-2772.

16 Lafreniere RG, Carrel L \& Willard HF. A novel transmembrane transporter encoded by the XPCT gene in Xq13.2. Human Molecular Genetics 19943 1133-1139.

17 Dumitrescu AM, Liao XH, Weiss RE, Millen K \& Refetoff S. Tissuespecific thyroid hormone deprivation and excess in monocarboxylate transporter (mct) 8-deficient mice. Endocrinology 2006147 4036-4043.

18 Trajkovic M, Visser TJ, Mittag J, Horn S, Lukas J, Darras VM, Raivich G, Bauer K \& Heuer H. Abnormal thyroid hormone metabolism in mice lacking the monocarboxylate transporter 8 . Journal of Clinical Investigation 2007117 627-635.

19 Dumitrescu AM, Liao XH, Best TB, Brockmann K \& Refetoff S. A novel syndrome combining thyroid and neurological abnormalities is associated with mutations in a monocarboxylate transporter gene. American Journal of Human Genetics $2004 \mathbf{7 4}$ $168-175$.

20 Friesema EC, Grueters A, Biebermann H, Krude H, von Moers A, Reeser M, Barrett TG, Mancilla EE, Svensson J, Kester MH, Kuiper GG, Balkassmi S, Uitterlinden AG, Koehrle J, Rodien P, Halestrap AP \& Visser TJ. Association between mutations in a thyroid hormone transporter and severe X-linked psychomotor retardation. Lancet $2004 \mathbf{3 6 4} 1435-1437$.

21 Samson M, Osty J, Francon J \& Blondeau JP. Triiodothyronine binding sites in the rat erythrocyte membrane: involvement in triiodothyronine transport and relation to the tryptophan transport system T. Biochimica et Biophysica Acta $1992 \mathbf{1 1 0 8}$ 91-98.

22 Zhou Y, Samson M, Osty J, Francon J \& Blondeau JP. Evidence for a close link between the thyroid hormone transport system and the aromatic amino acid transport system T in erythrocytes. Journal of Biological Chemistry 1990265 17000-17004.

23 Zhou Y, Samson M, Francon J \& Blondeau JP. Thyroid hormone concentrative uptake in rat erythrocytes. Involvement of the tryptophan transport system $\mathrm{T}$ in countertransport of triiodothyronine and aromatic amino acids. Biochemical Journal 1992281 81-86.

24 Kim DK, Kanai Y, Chairoungdua A, Matsuo H, Cha SH \& Endou H. Expression cloning of a $\mathrm{Na}^{+}$-independent aromatic amino acid transporter with structural similarity to $\mathrm{H}^{+}$/monocarboxylate transporters. Journal of Biological Chemistry $2001 \mathbf{2 7 6}$ 17221-17228.

25 Kim DK, Kanai Y, Matsuo H, Kim JY, Chairoungdua A, Kobayashi Y, Enomoto A, Cha SH, Goya T \& Endou H. The human T-type amino acid transporter-1: characterization, gene organization, and chromosomal location. Genomics 200279 95-103.

26 Friesema EC, Jansen J, Jachtenberg JW, Visser WE, Kester MH \& Visser TJ. Effective cellular uptake and efflux of thyroid hormone by human monocarboxylate transporter 10 (MCT10). Molecular Endocrinology 200822 1357-1369.

27 Van den Berghe G, Wouters P, Weekers F, Verwaest C, Bruyninckx F, Schetz M, Vlasselaers D, Ferdinande P, Lauwers P \& Bouillon R. Intensive insulin therapy in the critically ill patients. New England Journal of Medicine 2001345 1359-1367.

28 Weekers F, Van Herck E, Coopmans W, Michalaki M, Bowers CY, Veldhuis JD \& Van den Berghe G. A novel in vivo rabbit model of hypercatabolic critical illness reveals a biphasic neuroendocrine stress response. Endocrinology 2002143 764-774. 
29 Mebis L, Langouche L, Visser TJ \& Van den Berghe G. The type II iodothyronine deiodinase is up-regulated in skeletal muscle during prolonged critical illness. Journal of Clinical Endocrinology and Metabolism 200792 3330-3333.

30 van der Geyten S, Van den Eynde I, Segers IB, Kuhn ER \& Darras VM. Differential expression of iodothyronine deiodinases in chicken tissues during the last week of embryonic development. General and Comparative Endocrinology 2002128 65-73.

31 Schatz DL, Sheppard RH, Steiner G, Chandarlapaty CS \& de Veber GA. Influence of heparin on serum free thyroxine. Journal of Clinical Endocrinology and Metabolism 196929 1015-1022.

32 Morreale de EG, Pastor R, Obregon MJ \& Escobar del RF. Effects of maternal hypothyroidism on the weight and thyroid hormone content of rat embryonic tissues, before and after onset of fetal thyroid function. Endocrinology 1985117 1890-1900.

33 Morreale de EG, Calvo R, Escobar del RF \& Obregon MJ. Thyroid hormones in tissues from fetal and adult rats. Endocrinology 1994 $1342410-2415$

34 Peeters RP, van der Geyten S, Wouters PJ, Darras VM, van Toor H, Kaptein E, Visser TJ \& Van den Berghe G. Tissue thyroid hormone levels in critical illness. Journal of Clinical Endocrinology and Metabolism $2005906498-6507$.

35 Roberts LM, Woodford K, Zhou M, Black DS, Haggerty JE, Tate EH, Grindstaff KK, Mengesha W, Raman C \& Zerangue N. Expression of the thyroid hormone transporters monocarboxylate transporter- 8 (SLC16A2) and organic ion transporter-14 (SLCO1C1) at the blood-brain barrier. Endocrinology $20081496251-6261$.

36 Debaveye Y, Ellger B, Mebis L, Visser TJ, Darras VM \& Van den Berghe G. Effects of substitution and high-dose thyroid hormone therapy on deiodination, sulfoconjugation, and tissue thyroid hormone levels in prolonged critically ill rabbits. Endocrinology $20081494218-4228$.

37 Jansen J, Friesema EC, Milici C \& Visser TJ. Thyroid hormone transporters in health and disease. Thyroid 200515 757-768.

38 Kaptein EM, Robinson WJ, Grieb DA \& Nicoloff JT. Peripheral serum thyroxine, triiodothyronine and reverse triiodothyronine kinetics in the low thyroxine state of acute nonthyroidal illnesses. A noncompartmental analysis. Journal of Clinical Investigation $198269526-535$.

39 Kaptein EM, Feinstein EI, Nicoloff JT \& Massry SG. Serum reverse triiodothyronine and thyroxine kinetics in patients with chronic renal failure. Journal of Clinical Endocrinology and Metabolism 1983 $\mathbf{5 7} 181-189$.

40 Kaptein EM. Thyroid hormone metabolism and thyroid diseases in chronic renal failure. Endocrine Reviews 199617 45-63.

41 Vanhorebeek I, De Vos R, Mesotten D, Wouters PJ, Wolf-Peeters C \& Van den Berghe G. Protection of hepatocyte mitochondrial ultrastructure and function by strict blood glucose control with insulin in critically ill patients. Lancet $2005 \mathbf{3 6 5} 53-59$.

42 Bodoky G, Yang ZJ, Meguid MM, Laviano A \& Szeverenyi N. Effects of fasting, intermittent feeding, or continuous parenteral nutrition on rat liver and brain energy metabolism as assessed by 31P-NMR. Physiology and Behavior 199558 521-527.

43 Krenning EP, Docter R, Bernard B, Visser T \& Hennemann G. Decreased transport of thyroxine $\left(\mathrm{T}_{4}\right), 3,3^{\prime}, 5$-triiodothyronine $\left(\mathrm{T}_{3}\right)$ and $3,3^{\prime}, 5^{\prime}$-triiodothyronine $\left(\mathrm{rT}_{3}\right)$ into rat hepatocytes in primary culture due to a decrease of cellular ATP content and various drugs. FEBS Letters $1982140229-233$.

44 Lim CF, Docter R, Visser TJ, Krenning EP, Bernard B, van Toor H, de Jong M \& Hennemann G. Inhibition of thyroxine transport into cultured rat hepatocytes by serum of nonuremic critically ill patients: effects of bilirubin and nonesterified fatty acids. Journal of Clinical Endocrinology and Metabolism 199376 1165-1172.

45 Sarne DH \& Refetoff S. Measurement of thyroxine uptake from serum by cultured human hepatocytes as an index of thyroid status: reduced thyroxine uptake from serum of patients with nonthyroidal illness. Journal of Clinical Endocrinology and Metabolism 198561 1046-1052.

46 Vos RA, de Jong M, Bernard BF, Docter R, Krenning EP \& Hennemann G. Impaired thyroxine and 3,5,3'-triiodothyronine handling by rat hepatocytes in the presence of serum of patients with nonthyroidal illness. Journal of Clinical Endocrinology and Metabolism $1995 \mathbf{8 0} 2364-2370$.

47 Lim CF, Docter R, Krenning EP, van Toor H, Bernard B, de Jong M \& Hennemann G. Transport of thyroxine into cultured hepatocytes: effects of mild non-thyroidal illness and calorie restriction in obese subjects. Clinical Endocrinology $1994 \mathbf{4 0} 79-85$.

Received 29 April 2009

Accepted 12 May 2009 